\title{
FRACTURE PROPERTIES OF PLAIN AND \\ STEEL-POLYPROPYLENE-FIBER-REINFORCED HIGH-PERFORMANCE CONCRETE
}

\section{LASTNOSTI LOMA NAVADNEGA IN VISOKOZMOGLJIVEGA BETONA, OJAČANEGA S POLIPROPILENSKIMI VLAKNI}

\author{
Piotr Smarzewski, Danuta Barnat-Hunek \\ Lublin University of Technology, Faculty of Civil Engineering and Architecture, Nadbystrzycka Str. 40, 20-618 Lublin, Poland \\ p.smarzewski@pollub.pl
}

Prejem rokopisa - received: 2014-08-05; sprejem za objavo - accepted for publication: 2014-09-22

doi:10.17222/mit.2014.180

\begin{abstract}
The aim of this research was to establish the fracture properties of high-performance concrete (HPC) containing two widely used types of fibers. The experimental investigation consisted of the tests on cubes, cylinders and notched prismatic samples made of plain HPC and fiber HPC (FHCP) with variable contents of steel or/and polypropylene fibers ranging from $0.25 \%$ to $1 \%$. Extensive data on compressive, splitting and flexural tensile behaviors, modulus of elasticity and fracture energy were recorded and analyzed. The experimental investigations showed that HPC in fracture mode I exhibit brittle/softening behavior. The FHPC materials showed a more ductile behavior compared to that of the HPC materials. Fiber bridges cracked on the fracture surface during the loading and delayed cracking, thus the element did not break. The results of the bending tests showed an extended post-peak softening behavior. The shape of the descending branch was dependent on geometrical and mechanical properties as well as the quantity of the fibers used. The results of the research were evaluated and it was shown that the fibers contributed considerably to the structural integrity and stability of the HPC elements, thereby improving their durable service life.
\end{abstract}

Keywords: hybrid fibers, steel fibers, polypropylene fibers, high-perfomance concrete, mechanical testing, fracture properties

Namen tega članka je bil ugotoviti lomne lastnosti visokozmogljivega betona (HPC), ki je vseboval dve vrsti vlaken. Eksperimentalno delo je bilo na kockah, valjih in zarezanih prizmatičnih vzorcih, izdelanih iz navadnega HPC in z vlakni ojačanega HPC (FHCP) s spremenljivo vsebnostjo od $0,25 \%$ do $1 \%$ jeklenih in/ali polipropilenskih vlaken. Ugotovljeni in analizirani so bili obsežni podatki o vedenju pri tlačni, cepilni in upogibni natezni obremenitvi, o modulu elastičnosti in energiji loma. Preizkusi so pokazali, da prelom HPC v načinu I izkazuje krhko/mehčalno vedenje. FHPC-materiali so pokazali bolj duktilno vedenje v primerjavi s HPC-materiali. Vlaknasti mostovi so pokali na površini loma med obremenitvijo in so zadrževali pokanje, zato se element ni porušil. Rezultati upogibnega preizkusa so pokazali povečano mehčanje po vrhu. Oblika pojemajočih korakov je bila odvisna od geometričnih in mehanskih lastnosti, kot tudi od količine uporabljenih vlaken. Rezultati preiskav so bili ocenjeni in pokazalo se je, da vlakna občutno prispevajo k strukturni integriteti in stabilnosti HPC-elementov in s tem podaljšajo dobo uporabnosti.

Ključne besede: hibridna vlakna, jeklena vlakna, polipropilenska vlakna, visokozmogljiv beton, mehanski preizkusi, lomne lastnosti

\section{INTRODUCTION}

High-performance concrete (HPC) is a material frequently used in the building industry due to its durability. Concrete technology has developed at a rapid pace over the last two decades and the material performance has been significantly improved. Initially, the attention of the researchers was only focused on increasing the compressive strength. Nowadays, HPC with a compressive strength exceeding $100 \mathrm{MPa}$ can be readily designed and manufactured. However, the brittleness of concrete increases with an increase in its strength. The higher the strength of concrete, the lower is its ductility. Fibers are added to the matrix as a reinforcement to control the cracking, to increase the ductility and to improve the general ductility of a material. ${ }^{1-4}$ Fiberconcrete research has been conducted for over fifty years $^{5,6}$ and future directions for its development are still being set. ${ }^{7-9}$ Nowadays, there are numerous types of fibers made of different materials that are of different geometric properties. With each type of fiber certain properties of concrete can be improved. In order to improve mechanical properties, especially the tensile and flexural strengths and long-term concrete shrinkage, steel fibers are usually used. Low-modulus polypropylene fibers can reduce early-age shrinkage and help control the phenomenon of the spalling of concrete during fire. One of the recent concepts is the hybridization of fibers, the optimum combination of several kinds of fibers with different properties to create a complex composite with a very high resistance to cracking in a wide range of crack width. ${ }^{10}$ The hybrid-fiber-reinforced concrete is mainly used in underground waterproof projects, road and bridge engineering and seismic structures. A lot of research revealed that a hybrid of steel and polypropylene fiber in concrete exhibits composite advantages of the two-fiber material properties, improves the interface condition between cement and aggregate, enhances the medium continuity of concrete, and constraints the occurrence and development of concrete cracks. ${ }^{11-15}$ 
The basic parameter for measuring the fracture process in quasi-brittle materials is the fracture energy $\left(G_{\mathrm{F}}\right)$. The most common way to measure the fracture energy of concrete materials is the method proposed by RILEM TC 50-FMC. ${ }^{16}$ In order to analyze and compare the fracture behavior of high-performance concrete (HPC), steel-fiber-reinforced high-performance concrete (SFHPC), polypropylene-fiber-reinforced high-performance concrete (PFHPC) and hybrid (steel and polypropylene)-fiber-reinforced high-performance concrete (HFHPC), by varying the type, proportion and content of the fibers, it is necessary to evaluate the experimental fracture energy up to the value that is limited by the long sloping curve. This study evaluated the effects of the type and content of the fibers on the mechanical properties and fracture of FHPC. For this purpose, three-point bending tests on notched samples were carried out in accordance with RILEM TC $89-$ FMT $^{17,18}$ and the experimental fracture-energy values calculated up to the threshold criteria were compared.

\section{MATERIALS, SAMPLES AND THE TEST PROGRAM}

\subsection{Details of the materials and sample specifications}

The experimental examination was carried out on cubes, cylinders and notched prismatic samples made of HPC and FHPC with variable contents of steel fibers (SFHPC), polypropylene (PFHPC) or the hybrid (HFHPC). The following tests were conducted: compressive strength, splitting tensile strength, modulus of elasticity, and the three-point bending tests to determine the effects of the fiber type and its content on the compressive-tensile behavior, deflection and fracture energy. Sample specifications used in the test program are shown in Table 1.

\subsection{Mixture design and the sample-production process}

The following components were used in the recipes for the concrete mixtures: Portland cement CEM I 52.5 N-HSR/NA, two types of the coarse aggregate - granodiorite or granite, quartz sand, water, condensed silica fume and superplasticizer. The maximum size of the coarse aggregate was $8 \mathrm{~mm}$. The silica fume in the form of powder had a specific surface of $15-30 \mathrm{~m}^{2} / \mathrm{g}$. Baumix steel fibers, hooked-end, with a $1100 \mathrm{MPa}$ tensile strength, $200 \mathrm{GPa}$ modulus of elasticity, $50 \mathrm{~mm}$ length and an aspect ratio of 50 were used. Polypropylene fibers Baucon had a length of $12 \mathrm{~mm}$ and a modulus of elasticity of 3.5 GPa.

The tests on the CEM I $52.5 \mathrm{~N}-\mathrm{HSR} / \mathrm{NA}$ cement were carried out according to the Polish standards. ${ }^{19,20} \mathrm{~A}$ chemical analysis was performed, the cement composition was determined and the results obtained are shown in Tables 2 and 3. The determination of the particle-size distribution for the granodiorite and granite aggregates as well as quartz sand was performed in line with the standard. ${ }^{21}$

Table 2: Chemical composition of cement in mass fractions, $w / \%$ Tabela 2: Kemijska sestava cementa v masnih deležih, w/\%

\begin{tabular}{|c|c|}
\hline Cement component & Content, $w / \%$ \\
\hline $\mathrm{SiO}_{2}$ & 20.92 \\
\hline $\mathrm{Al}_{2} \mathrm{O}_{3}$ & 3.50 \\
\hline $\mathrm{Fe}_{2} \mathrm{O}_{3}$ & 4.38 \\
\hline $\mathrm{CaO}$ & 64.69 \\
\hline $\mathrm{MgO}$ & 1.20 \\
\hline $\mathrm{SO}_{3}$ & 3.07 \\
\hline $\mathrm{Na}_{2} \mathrm{O}$ & 0.22 \\
\hline $\mathrm{K}_{2} \mathrm{O}$ & 0.38 \\
\hline $\mathrm{Cl}$ & 0.082 \\
\hline Ignition loss & 1.27 \\
\hline $\mathrm{Ash}$ & 0.26 \\
\hline Total & 99.97 \\
\hline
\end{tabular}

Table 3: Cement technical parameters

Tabela 3: Tehnični parametri cementa

\begin{tabular}{|l|c|}
\hline \multicolumn{1}{|c|}{ Cement characteristics } & $\begin{array}{c}\text { CEM I 52.5 } \\
\text { N-HSR/NA }\end{array}$ \\
\hline Specific surface area $\left(\mathrm{cm}^{2} / \mathrm{g}\right)$ & 4433 \\
\hline Water demand $(\%)$ & 30 \\
\hline Commencement of bonding (min) & 120 \\
\hline End of bonding (min) & 180 \\
\hline $\begin{array}{l}\text { Volume stability according to Le Chateliere } \\
\text { (mm) }\end{array}$ & 2.00 \\
\hline Compressive strength after 2 d $(\mathrm{MPa})$ & 27.7 \\
\hline Compressive strength after 28 d $(\mathrm{MPa})$ & 57.1 \\
\hline Tensile strength after 2 d $(\mathrm{MPa})$ & 5.29 \\
\hline Tensile strength after 28 d $(\mathrm{MPa})$ & 8.23 \\
\hline
\end{tabular}

Table 1: Sample specifications

Tabela 1: Specifikacija vzorcev

\begin{tabular}{|c|c|c|c|c|c|c|c|}
\hline Label & HPC1 & SFHPC & HFHPC1 & HFHPC2 & HFHPC3 & PFHPC & HPC2 \\
\hline Fiber type & - & Steel $(\mathrm{S})$ & $\begin{array}{l}\text { Hybrid } \\
(\mathrm{S}+\mathrm{P})\end{array}$ & $\begin{array}{l}\text { Hybrid } \\
(\mathrm{S}+\mathrm{P}) \\
\end{array}$ & $\begin{array}{l}\text { Hybrid } \\
(\mathrm{S}+\mathrm{P})\end{array}$ & $\begin{array}{l}\text { Polypropy- } \\
\text { lene (P) }\end{array}$ & - \\
\hline$L_{\mathrm{f}} / \mathrm{mm}$ & - & 50 & $50 / 12$ & $50 / 12$ & $50 / 12$ & 12 & - \\
\hline$V_{\mathrm{f}} / \%$ & 0 & 1 & $0.75+0.25$ & $0.5+0.5$ & $0.25+0.75$ & 1 & 0 \\
\hline \multicolumn{8}{|c|}{ Number of the tested samples } \\
\hline Compression test & 3 & 3 & 3 & 3 & 3 & 3 & 3 \\
\hline Splitting tensile test & 3 & 3 & 3 & 3 & 3 & 3 & 3 \\
\hline Modulus of elasticity test & 3 & 3 & 3 & 3 & 3 & 3 & 3 \\
\hline Three point bending test & 3 & 3 & 3 & 3 & 3 & 3 & 3 \\
\hline
\end{tabular}


Table 4: Mixture proportions

Tabela 4: Razmerja mešanic

\begin{tabular}{|c|c|c|c|c|c|c|c|c|}
\hline Material & Symbol, unit & HPC1 & SFHPC & HFHPC1 & HFHPC2 & HFHPC3 & PFHPC & $\mathrm{HPC} 2$ \\
\hline Cement & $c /\left(\mathrm{kg} / \mathrm{m}^{3}\right)$ & 670.5 & 670.5 & 670.5 & 670.5 & 670.5 & 670.5 & 670.5 \\
\hline Quartz sand 0/2 mm & $s /\left(\mathrm{kg} / \mathrm{m}^{3}\right)$ & 500 & 500 & 500 & 500 & 500 & 500 & 500 \\
\hline Granodiorite $2 / 8 \mathrm{~mm}$ & $a_{1} /\left(\mathrm{kg} / \mathrm{m}^{3}\right)$ & 990 & 990 & 990 & - & - & - & - \\
\hline Granite $2-8 \mathrm{~mm}$ & $a_{2} /\left(\mathrm{kg} / \mathrm{m}^{3}\right)$ & - & - & - & 990 & 990 & 990 & 990 \\
\hline \multirow[t]{2}{*}{ Silica fume } & $s f /\left(\mathrm{kg} / \mathrm{m}^{3}\right)$ & 74.5 & 74.5 & 74.5 & 74.5 & 74.5 & 74.5 & 74.5 \\
\hline & $(s f / c) / \%$ & 11 & 11 & 11 & 11 & 11 & 11 & 11 \\
\hline \multirow[t]{2}{*}{ Superplasticizer } & $s p /\left(\mathrm{L} / \mathrm{m}^{3}\right)$ & 20 & 20 & 20 & 20 & 20 & 20 & 20 \\
\hline & $s p /(c+s f) / \%$ & 2.7 & 2.7 & 2.7 & 2.7 & 2.7 & 2.7 & 2.7 \\
\hline \multirow[t]{2}{*}{ Water } & $w /\left(\mathrm{L} / \mathrm{m}^{3}\right)$ & 178 & 178 & 178 & 178 & 178 & 178 & 178 \\
\hline & $w /(c+s f)$ & 0.24 & 0.24 & 0.24 & 0.24 & 0.24 & 0.24 & 0.24 \\
\hline \multirow[t]{2}{*}{ Steel fiber } & $w_{\mathrm{fs}} /\left(\mathrm{kg} / \mathrm{m}^{3}\right)$ & - & 78 & 58.5 & 29.25 & 19.5 & - & - \\
\hline & $V_{\mathrm{fs}} / \%$ & 0 & 1 & 0.75 & 0.5 & 0.25 & 0 & 0 \\
\hline \multirow[t]{2}{*}{ Polypropylene fiber } & $w_{\mathrm{fp}} /\left(\mathrm{kg} / \mathrm{m}^{3}\right)$ & - & - & 2.25 & 4.5 & 6.75 & 9 & - \\
\hline & $V_{\mathrm{fp}} / \%$ & 0 & 0 & 0.25 & 0.5 & 0.75 & 1 & 0 \\
\hline
\end{tabular}

In order to attain the same workability, the ISOFLEX CX 793 superplasticizer based on polycarboxylate ethers with a density of $1.065 \mathrm{~g} / \mathrm{cm}^{3}$ at $20{ }^{\circ} \mathrm{C}$ was used in all the concrete mixtures. The HPC and FHPC mix designs per cubic meter of the concrete used in the experimental program are shown in Table 4.

The mixtures were prepared using a typical concrete mixer with a capacity of $100 \mathrm{~L}$. The mixing procedure was as follows: quartz sand and coarse aggregate were homogenized together and mixed with half a quantity of water. Then, cement, silica fume, the remaining water and, finally, the superplasticizer were added. After the components were thoroughly mixed, the fibers were gradually added by hand to obtain homogeneous and workable mixtures. Molds coated with an anti-adhesive substance were filled with the concrete batch that was compacted on a vibrating table. After the compacting, the samples were covered with a foil to minimize the loss of moisture. All the samples were stored at a temperature of about $23{ }^{\circ} \mathrm{C}$ until removing them from the moulds after $24 \mathrm{~h}$ and they were placed into a water tank for $7 \mathrm{~d}$ to cure. After $7 \mathrm{~d}$ the samples were removed from the tank to cure in the laboratory conditions for up to $28 \mathrm{~d}$.

\subsection{Test equipment and solutions}

Compressive and splitting tensile tests were carried out after $28 \mathrm{~d}$, in accordance with the standards, ${ }^{22,23}$ using $100 \mathrm{~mm}$ cubes. A Walter-Bai AG servo-hydraulic closed-loop testing machine with a capacity of $3 \mathrm{MN}$ was used.

The test method for the static modulus of elasticity of concrete in compression was performed on the cylinders with a $150 \mathrm{~mm}$ diameter and a height of $300 \mathrm{~mm}$, measuring the deformation stress of the samples in the range from $0.5 \mathrm{MPa}$ to $30 \%$ of the concrete compressive strength. The examination was conducted by means of a Walter-Bai AG press and a modulus-measuring device with an extensometer in line with the recommendations of ASTM. ${ }^{24}$

Three-point bending tests were also performed after $28 \mathrm{~d}$ on a MTS 809 axial/torsional testing system machine, in accordance with RILEM TC 89 -FMT, ${ }^{17}$ using $80 \mathrm{~mm} \times 150 \mathrm{~mm} \times 700 \mathrm{~mm}$ prismatic samples (Figure 1a). In the mid-span of each sample, a single notch was made with a concreting flat iron sharpened at its tip, with a thickness of $3 \mathrm{~mm}$ and a depth of $50 \mathrm{~mm}$, in order to locate the cracks. Before the testing, the samples were provided with plaques for fixing the clip gauge thereon. (a)

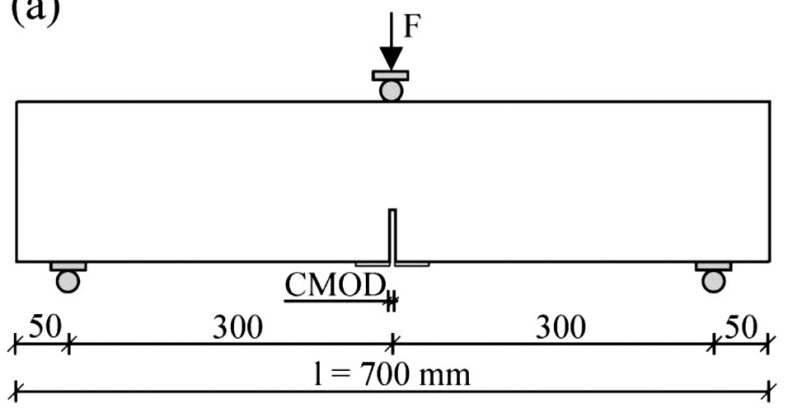

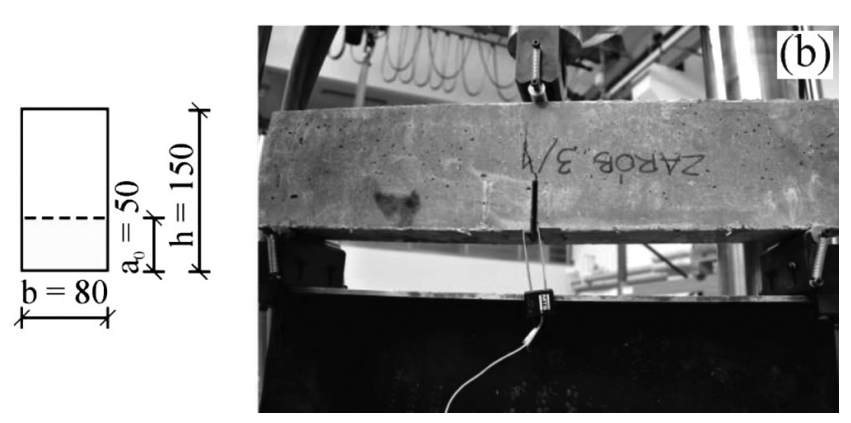

Figure 1: Three-point bending test: a) sample geometry and dimensions, b) experimental-set up Slika 1: Tritočkovni upogibni preizkus: a) geometrija vzorca in dimenzije, b) eksperimentalni sestav 
The tests were conducted by imposing a displacement rate of $0.05 \mathrm{~mm} / \mathrm{min}$. In order to measure the crackmouth-opening displacement (CMOD), a strain gauge consisting of elastic plates separated by means of a non-conductive cube was used (Figure 1b). It was provided from the outside to the system for an automatic detection of the CMOD values corresponding to the loads applied.

\section{RESULTS AND DISCUSSION}

\subsection{Compressive strength}

The cube compressive peak strength of each sample, the mean values of the compressive strength, the standard deviation and the coefficient of variation are given in Table 5. The cube compressive strength was insignificantly affected by adding steel and polypropylene fibers; however, a higher decrease in the compression strength was observed when the percent of the polypropylene-fiber volume added was higher. This was mainly due to the low modulus of elasticity of the propylene fibers and to some difficulties in dispersing the fibers in the mixtures. It should be noted that at a $1 \%$ fiber volume in PFHPC, it had $73 \%$ of the strength of the HPC2 fiber-free cube made of the same aggregate, whereas at the polypropylene-fiber volume of $0.75 \%$ and the steel fibers of $0.25 \%$, the strength of the cube made of HFHPC was about $95 \%$ of the HPC2 strength.

Table 5: Cube compressive strength

Tabela 5: Tlačna trdnost kock

\begin{tabular}{|c|c|c|c|c|}
\hline $\begin{array}{c}\text { Mixture } \\
\text { designation }\end{array}$ & $\begin{array}{l}\text { Compressi- } \\
\text { ve strength } \\
\mathrm{MPa}\end{array}$ & $\begin{array}{c}\text { Mean value } \\
\mathrm{MPa}\end{array}$ & $\begin{array}{c}\text { Standard } \\
\text { deviation } \\
\mathrm{MPa}\end{array}$ & $\begin{array}{c}\text { Coefficient } \\
\text { of variation } \\
\%\end{array}$ \\
\hline \multirow{3}{*}{ HPC1 } & 146.4 & \multirow{3}{*}{151.0} & \multirow{3}{*}{4.1} & \multirow{3}{*}{2.7} \\
\hline & 152.3 & & & \\
\hline & 154.4 & & & \\
\hline \multirow{3}{*}{ SFHPC } & 158.0 & \multirow{3}{*}{154.9} & \multirow{3}{*}{2.9} & \multirow{3}{*}{1.9} \\
\hline & 152.2 & & & \\
\hline & 154.6 & & & \\
\hline \multirow{3}{*}{ HFHPC1 } & 142.5 & \multirow{3}{*}{144.7} & \multirow{3}{*}{3.4} & \multirow{3}{*}{2.3} \\
\hline & 143.1 & & & \\
\hline & 148.6 & & & \\
\hline \multirow{3}{*}{ HFHPC2 } & 132.5 & \multirow{3}{*}{133.9} & \multirow{3}{*}{3.8} & \multirow{3}{*}{2.9} \\
\hline & 138.2 & & & \\
\hline & 130.9 & & & \\
\hline \multirow{3}{*}{ HFHPC3 } & 124.1 & \multirow{3}{*}{122.3} & \multirow{3}{*}{2.0} & \multirow{3}{*}{1.7} \\
\hline & 120.1 & & & \\
\hline & 122.7 & & & \\
\hline \multirow{3}{*}{ PFHPC } & 94.8 & \multirow{3}{*}{94.6} & \multirow{3}{*}{1.3} & \multirow{3}{*}{1.4} \\
\hline & 95.8 & & & \\
\hline & 93.2 & & & \\
\hline \multirow{3}{*}{ HPC2 } & 130.6 & \multirow{3}{*}{129.5} & \multirow{3}{*}{3.8} & \multirow{3}{*}{2.9} \\
\hline & 125.3 & & & \\
\hline & 132.6 & & & \\
\hline
\end{tabular}

\subsection{Splitting tensile strength}

The cube peak-splitting tensile strength for each sample, the mean values of the splitting tensile strength, the standard deviation and the coefficient of variation are shown in Table 6. The addition of the fibers significantly affected the cube splitting tensile strength; however, a higher increase was observed at a higher percent of the steel fibers added. It was noted that at a $1 \%$ steel-fiber volume in SFHPC, the cube strength increased by $55 \%$ compared to the HPC1 fiber-free cube. A similar increase in the strength was observed for HFHPC at a $0.75 \%$ steel-fiber volume and $0.25 \%$ polypropylenefiber volume. Lower increases in the strength of $12 \%$ were obtained at a $1 \%$ polypropylene-fiber volume in PFHPC compared to the HPC2 fiber-free cube.

Table 6: Cube splitting tensile strength

Tabela 6: Natezna trdnost cepljenja kock

\begin{tabular}{|c|c|c|c|c|}
\hline $\begin{array}{c}\text { Mixture } \\
\text { designation }\end{array}$ & $\begin{array}{l}\text { Splitting } \\
\text { tensile } \\
\text { strength } \\
\mathrm{MPa}\end{array}$ & $\begin{array}{c}\text { Mean value } \\
\mathrm{MPa}\end{array}$ & $\begin{array}{c}\text { Standard } \\
\text { deviation } \\
\mathrm{MPa}\end{array}$ & $\begin{array}{c}\text { Coefficient } \\
\text { of variation } \\
\%\end{array}$ \\
\hline \multirow{3}{*}{ HPC1 } & 8.9 & \multirow{3}{*}{8.9} & \multirow{3}{*}{0.4} & \multirow{3}{*}{4.7} \\
\hline & 9.3 & & & \\
\hline & 8.5 & & & \\
\hline \multirow{3}{*}{ SFHPC } & 14.0 & \multirow{3}{*}{13.8} & \multirow{3}{*}{0.1} & \multirow{3}{*}{1.0} \\
\hline & 13.8 & & & \\
\hline & 13.7 & & & \\
\hline \multirow{3}{*}{ HFHPC1 } & 13.8 & \multirow{3}{*}{13.5} & \multirow{3}{*}{0.2} & \multirow{3}{*}{1.7} \\
\hline & 13.3 & & & \\
\hline & 13.5 & & & \\
\hline \multirow{3}{*}{ HFHPC2 } & 10.4 & \multirow{3}{*}{10.0} & \multirow{3}{*}{0.4} & \multirow{3}{*}{3.8} \\
\hline & 9.6 & & & \\
\hline & 10.1 & & & \\
\hline \multirow{3}{*}{ HFHPC3 } & 9.5 & \multirow{3}{*}{9.3} & \multirow{3}{*}{0.2} & \multirow{3}{*}{1.9} \\
\hline & 9.3 & & & \\
\hline & 9.2 & & & \\
\hline \multirow{3}{*}{ PFHPC } & 7.4 & \multirow{3}{*}{7.6} & \multirow{3}{*}{0.2} & \multirow{3}{*}{3.1} \\
\hline & 7.7 & & & \\
\hline & 7.9 & & & \\
\hline \multirow{3}{*}{ HPC2 } & 7.1 & \multirow{3}{*}{6.8} & \multirow{3}{*}{0.3} & \multirow{3}{*}{4.5} \\
\hline & 6.7 & & & \\
\hline & 6.5 & & & \\
\hline
\end{tabular}

\subsection{Modulus of elasticity}

The cylinder modulus of elasticity for each sample, the mean values of the modulus of elasticity, the standard deviation and the coefficient of variation are shown in Table 7. The value of the cylinder elasticity modulus was only slightly affected by adding the steel fibers and it increased with their volume fraction added. This was mainly due to the high modulus of elasticity of the steel fibers. It should be noted that at a $1 \%$ fiber volume in SFHPC, the cylinder modulus of elasticity was $4 \%$ higher than that of the HPC1 fiber-free cylinder. At a lower content of the steel fibers, the modulus value was gradually decreased and at a $0.25 \%$ fiber volume in the 
cylinder made of HFHPC3, the modulus value was lower by $10 \%$ compared to that of the HPC2 standard concrete.

Table 7: Cylinder modulus of elasticity

Tabela 7: Modul elastičnosti valjastih vzorcev

\begin{tabular}{|c|c|c|c|c|}
\hline $\begin{array}{c}\text { Mixture } \\
\text { designation }\end{array}$ & $\begin{array}{c}\text { Modulus of } \\
\text { elasticity } \\
\text { MPa }\end{array}$ & $\begin{array}{c}\text { Mean value } \\
\text { MPa }\end{array}$ & $\begin{array}{c}\text { Standard } \\
\text { deviation } \\
\mathrm{MPa}\end{array}$ & $\begin{array}{c}\text { Coefficient } \\
\text { of variation } \\
\%\end{array}$ \\
\hline HPC1 & $\begin{array}{l}38381 \\
38645 \\
38087\end{array}$ & 38371 & 279 & 0.7 \\
\hline SFHPC & $\begin{array}{l}39767 \\
39466 \\
39986\end{array}$ & 39740 & 261.1 & 0.7 \\
\hline HFHPC1 & $\begin{array}{l}34266 \\
33987 \\
34562\end{array}$ & 34272 & 287.5 & 0.8 \\
\hline 1HFHPC2 & $\begin{array}{l}32890 \\
32355 \\
32096\end{array}$ & 32447 & 404.9 & 1.2 \\
\hline HFHPC3 & $\begin{array}{l}29870 \\
29264 \\
29763\end{array}$ & 29632 & 323.4 & 1.1 \\
\hline PFHPC & $\begin{array}{l}29641 \\
29455 \\
29179 \\
\end{array}$ & 29425 & 232.5 & 0.8 \\
\hline HPC2 & $\begin{array}{l}32322 \\
32780 \\
32542\end{array}$ & 32548 & 229.1 & 0.7 \\
\hline
\end{tabular}

\subsection{Flexural tensile behavior}

The behavior of the HPC ordinary concrete samples during the bending test was almost linear-elastic up to the peak-load values, then the curve was sloping until the complete separation of the samples into two parts. The FRC samples showed a trilinear variation with the significant cracking between the first crack load and the peak load.

The typical experimental load $(F)$ - deflection $(\delta)$ curves for the selected samples SFHPC, PFHPC and HFHPC - recorded during the bending tests, are shown in Figure 2. The examination was carried out in two stages. During the first stage, the crack-mouth-opening displacement (CMOD) and deflection were measured until the cracking of the beams along the whole height. After dismantling the strain gauge only deflection was recorded.

A typical generic curve of the FRC samples is characterized with a linear curve up to the first crack, and then with the non-linear behavior up to the peak load. After reaching the peak load, the load-carrying capacity declines; however, the higher the loss of the strength, the lower is the steel-fiber content. As micro-cracks grow and join into larger macro-cracks, the long hooked-end fibers become engaged in crack bridging. Compared to the high-performance concrete, the peak load increases when steel fibers are used as shown in Figure $\mathbf{3}$ and Table 8.
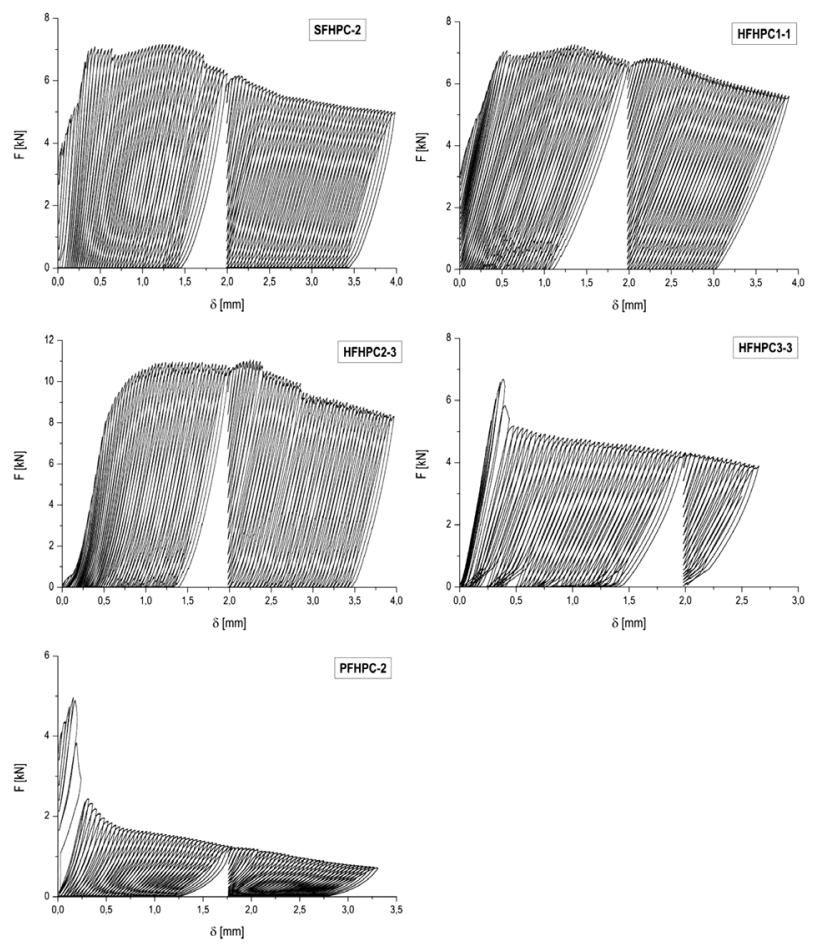

Figure 2: Typical experimental load-deflection curves for the FHPC notched prismatic samples

Slika 2: Značilne krivulje obremenitev - deformacija prizmatičnih FHPC-vzorcev z zarezo
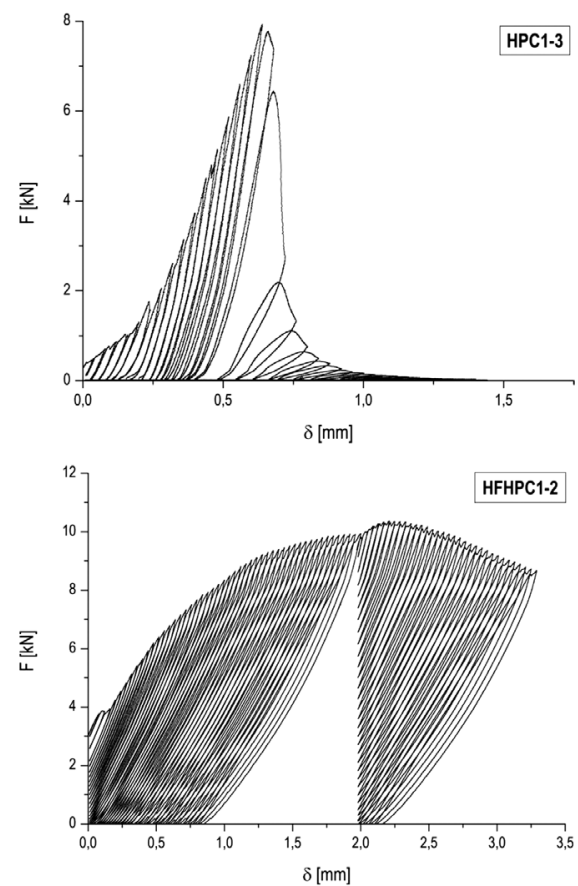

Figure 3: Typical experimental load-deflection curves for HPC and HFHPC

Slika 3: Značilne eksperimentalne krivulje obremenitev - deformacija za HPC in HFHPC

In particular, with respect to the typical curves for SFHPC, the peak load is increased by $17 \%$, compared to that of HPC1. An even higher increase of $92 \%$ was 
obtained for the HFHPC2 batch (from $0.5 \%$ of steel fibers and $0.5 \%$ of polypropylene) compared to HPC 2 .

The PFHPC samples with a low modulus of fibers of $1 \%$ achieved similar peak-load values for the HPC2 samples. A very high coefficient of variation was observed for the steel-fiber-reinforced batch, which indicated that the decisive factor in obtaining the peak-load values was the amount of the longitudinally oriented fibers.

Table 8: Three-point bending tests Tabela 8: Tritočkovni upogibni preizkusi

\begin{tabular}{|c|c|c|c|c|}
\hline $\begin{array}{c}\text { Mixture } \\
\text { designation }\end{array}$ & $\begin{array}{c}\text { Peak load } \\
\text { kN }\end{array}$ & $\begin{array}{c}\text { Mean value } \\
\mathrm{kN}\end{array}$ & $\begin{array}{c}\text { Standard } \\
\text { deviation } \\
\text { kN }\end{array}$ & $\begin{array}{c}\text { Coefficient } \\
\text { of variation } \\
\%\end{array}$ \\
\hline HPC1 & $\begin{array}{l}7.5 \\
7.0 \\
7.9\end{array}$ & 7.5 & 0.4 & 6.0 \\
\hline SFHPC & $\begin{array}{l}12.1 \\
7.1 \\
7.1\end{array}$ & 8.8 & 2.9 & 32.9 \\
\hline HFHPC1 & $\begin{array}{c}7.3 \\
10.6 \\
8.2 \\
\end{array}$ & 8.7 & 1.7 & 19.6 \\
\hline HFHPC2 & $\begin{array}{c}6.2 \\
12.3 \\
11.0 \\
\end{array}$ & 9.8 & 3.2 & 32.7 \\
\hline HFHPC3 & $\begin{array}{l}8.5 \\
7.0 \\
6.8 \\
\end{array}$ & 7.4 & 0.9 & 12.5 \\
\hline PFHPC & $\begin{array}{l}5.1 \\
5.0 \\
5.4\end{array}$ & 5.2 & 0.2 & 4.0 \\
\hline HPC2 & $\begin{array}{l}5.0 \\
5.0 \\
5.3\end{array}$ & 5.1 & 0.2 & 3.4 \\
\hline
\end{tabular}

\subsection{Fracture properties}

In order to describe the FHPC post-cracking enhancement, different toughness indexes were proposed. RILEM proposed the concept of an equivalent flexural tensile strength, $f_{\mathrm{eq}} \cdot{ }^{25}$ Recently, RILEM proposed the concept of a residual flexural tensile strength, $f_{\mathrm{R}}$, which is more readily assessed. ${ }^{26}$ According to RILEM, recently recommended $f_{\mathrm{eq}, 2}$ or $f_{\mathrm{R}, 1}$ are used in the verification of the serviceability limit states, and $f_{\text {eq. } 3}$ or $f_{\mathrm{R}, 4}$ are applied in the ultimate limit-state analysis. ${ }^{27}$ These parameters are also used to determine the stress-strain curves which are useful in modeling the FHPC postcracking behavior.

With regard to the experimental curves, the load at the limit of proportionality, $F_{\mathrm{L}}$, the corresponding strength, $f_{\text {fct,L }}$, the equivalent flexural strengths, $f_{\text {eq, } 2}$ and $f_{\mathrm{eq}, 3}$, and the residual flexural strengths, $f_{\mathrm{R}, 1}$ and $f_{\mathrm{R}, 4}$, relating to the mid-span deflections of $0.46 \mathrm{~mm}$ and 3.00 $\mathrm{mm}$, were evaluated. The load at the limit of proportionality $F_{\mathrm{L}}$ is equal to the highest value of the load recorded up to a deflection of $0.05 \mathrm{~mm}$. The strength corresponding to the limit of proportionality can be computed using the following equation:

$$
f_{\mathrm{f}_{\mathrm{ct}}, \mathrm{L}}=\frac{2 F_{\mathrm{L}} l}{2 b\left(h-a_{0}\right)^{2}}(\mathrm{MPa})
$$

where $b=80 \mathrm{~mm}, h=150 \mathrm{~mm}$ and $l=600 \mathrm{~mm}$ relate to the width, the height and the span of the samples tested, $a_{0}=50 \mathrm{~mm}$ is the notch depth and $\left(h-a_{0}\right)$ is the distance between the tip of the notch and the top edge of a sample.

The parameters $f_{\text {eq, } 2}$ and $f_{\text {eq, } 3}$ were evaluated up to the deflections of $\delta_{2}=\delta_{\mathrm{L}}+0.65 \mathrm{~mm}$ and $\delta_{3}=\delta_{\mathrm{L}}+2.65 \mathrm{~mm}$, where $\delta_{\mathrm{L}}$ is the deflection corresponding to $F_{\mathrm{L}}$. The portion of the energy required by the fracture of the concrete corresponding to the OBA field in Figure 4 $\left(D^{\mathrm{b}}{ }_{\mathrm{OAB}}\right)$ was not considered in assessing the equivalent flexural strength. Only the effect of the fibers was considered $\left(\mathrm{ABCD}-D_{\mathrm{BZ}, 2}^{\mathrm{f}}\right.$ and $\mathrm{EFGH}-D_{\mathrm{BZ}, 3}^{\mathrm{f}}$ in Figure 4). The equivalent flexural strength was calculated from the following expressions:

$$
\begin{aligned}
& f_{\text {eq }, 2}=\frac{3 l}{2 b\left(h-a_{0}\right)^{2}} \frac{D_{\mathrm{BZ}, 2}^{\mathrm{f}}}{0.5}(\mathrm{MPa}) \\
& f_{\mathrm{eq}, 3}=\frac{3 l}{2 b\left(h-a_{0}\right)^{2}} \frac{D_{\mathrm{BZ}, 3}^{\mathrm{f}}}{2.5}(\mathrm{MPa})
\end{aligned}
$$

The residual flexural tensile strengths $f_{\mathrm{R}, 1}$ and $f_{\mathrm{R}, 4}$ at the mid-span deflections of $0.46 \mathrm{~mm}$ and $3.00 \mathrm{~mm}$, respectively, were computed according to:

$$
\begin{aligned}
f_{\mathrm{R}, 1} & =\frac{3 F_{\mathrm{R}, 1} l}{2 b\left(h-a_{0}\right)^{2}}(\mathrm{MPa}) \\
f_{\mathrm{R}, 4} & =\frac{3 F_{\mathrm{R}, 4} l}{2 b\left(h-a_{0}\right)^{2}}(\mathrm{MPa})
\end{aligned}
$$

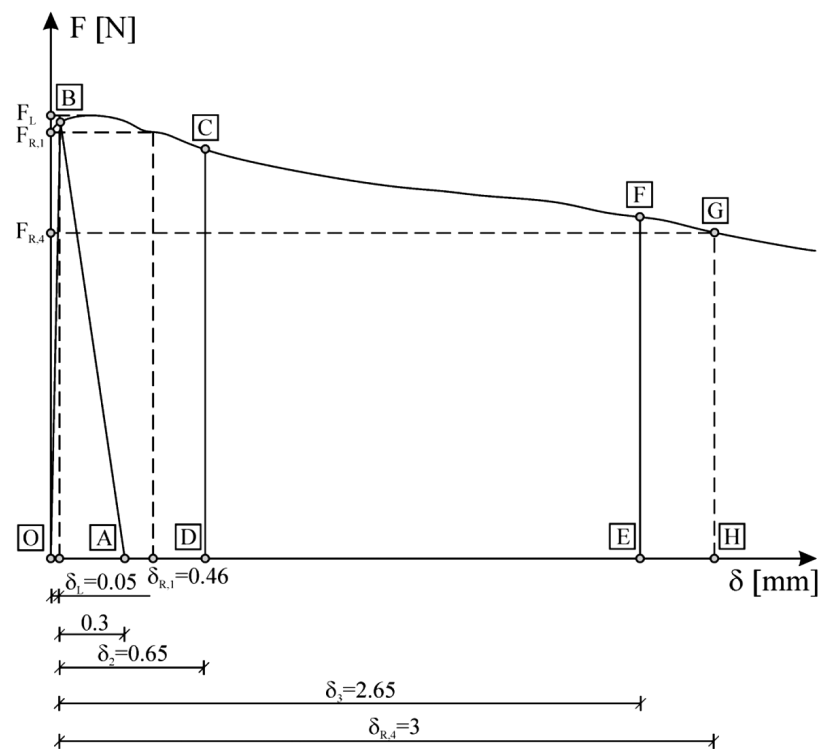

Figure 4: Evaluation of flexural-tensile-strength parameters according to RILEM TC 162-TDF

Slika 4: Vrednotenje parametrov upogibne natezne trdnosti skladno z RILEM TC 162-TDF 
The energy dissipation in the fractured concrete is the most advantageous characteristic of FHPC due to the addition of the fibers to the material. The fracture energy $\left(G_{\mathrm{F}}\right)$ was computed as the area under the stress-displacement curves. Assuming a linear stress distribution in relation to the fracture depth, the tensile stress was calculated according to the following formula:

$$
\sigma=\frac{3 F l}{2 b\left(h-a_{0}\right)^{2}}(\mathrm{MPa})
$$

where $F$ is the load recorded during the three-point bending test.

The fracture energy was computed up to the predetermined load-deflection point based on the following formula:

$$
G_{\mathrm{F}}=\int_{\delta=0}^{\delta=\delta_{\lim }} \sigma \mathrm{d} \delta(\mathrm{N} / \mathrm{mm})
$$

The fracture energy for the FRC samples needs to be computed in relation to the specified value of the displacement. A reliable cut-off point can be selected at a $10 \mathrm{~mm}$ displacement. ${ }^{28}$ However, only a fracture dissipated up to a deflection of $3 \mathrm{~mm}$ seems to be interesting from the design viewpoint ${ }^{29}$ and such a deflection value was adopted while computing energy in this work. The results of the strength parameters and the fracture energy are included in Table 9.

Referring to the data given in Table 9, it is noteworthy that the flexural-strength values obtained from Equations (2) and (3) lead to similar strength values in the cases of steel and hybrid fibers. The samples with the addition of polypropylene fibers only constitute an exception. For all kinds of fibers, the equivalent flexural-strength values are lower than the strengths at the limit of proportionality given with Equation (1). The highest differences were observed for the polypropylene fibers. The obtained results emphasize the effect of the elasticity modulus on the variation in the HPC fracture properties. It can be seen that in FHPC the highest fracture energy was obtained with the addition of steel and polypropylene fibers, $0.5 \%$ of each. The percentage volume of the steel fibers accounted for the fractureenergy increase. When decreasing the fiber content from $1 \%$ to $0.75 \%$, the HFHPC- 1 samples showed a decrease in the fracture energy by approximately $7 \%$ compared to the SFHPC samples. The $G_{\mathrm{F}}$ values for the batches with the hybrid, steel-polypropylene fibers are due to the volume content of the low-modulus fibers. The higher the volume content of the low-modulus fibers, the lower are the $G_{\mathrm{F}}$ values obtained. The results of the fracture energy from Table 9 show that the ductility of the FHPC material at a high level of the strain depends largely on the capability of the fibers to bridge the cracks. Stiffer steel fibers provide a higher resistance to the loads whereas polypropylene fibers of a low modulus of elasticity provide a higher resistance to shrinkage and temperature stress. Therefore, it seems appropriate to combine the fibers of high and low modulus which can result in a longer period of durable service life.

In the case of two batches of the HPC samples, a brittle fracture occurred through a separation of the elements into two parts (Figure 5).

The FHPC samples with cracks underwent a significant deflection; however, not in all the cases the brittle

Table 9: Tensile-strength parameters and experimental fracture energy

\begin{tabular}{|c|c|c|c|c|c|c|c|}
\hline Mixture designation & $F_{\mathrm{L}} / \mathrm{kN}$ & $f_{\text {fct, } \mathrm{L}} / \mathrm{MPa}$ & $f_{\mathrm{eq}, 2} / \mathrm{MPa}$ & $f_{\mathrm{eq}, 3} / \mathrm{MPa}$ & $f_{\mathrm{R}, 1} / \mathrm{MPa}$ & $f_{\mathrm{R}, 4} / \mathrm{MPa}$ & $G_{\mathrm{F}} /(\mathrm{N} / \mathrm{mm})$ \\
\hline SFHPC-1 & 12.1 & 13.5 & 6.4 & 12.3 & 5.7 & 12.6 & 32.3 \\
\hline SFHPC-2 & 7.1 & 8.0 & 7.0 & 6.9 & 7.9 & 6.1 & 17.1 \\
\hline SFHPC-3 & 7.1 & 8.0 & 7.4 & 7.5 & 7.9 & 6.1 & 19.0 \\
\hline Mean value & 8.8 & 9.7 & 6.9 & 8.9 & 7.2 & 8.3 & 22.8 \\
\hline Standard deviation & 2.9 & 2.9 & 0.5 & 3.0 & 1.3 & 3.7 & 8.3 \\
\hline HFHPC1-1 & 7.3 & 8.2 & 6.6 & 7.5 & 6.8 & 7.1 & 18.8 \\
\hline HFHPC1-2 & 10.6 & 11.9 & 6.1 & 9.7 & 6.8 & 10.6 & 24.9 \\
\hline HFHPC $1-3$ & 8.2 & 9.2 & 7.8 & 8.3 & 8.4 & 9.1 & 19.9 \\
\hline Mean value & 8.7 & 9.8 & 6.8 & 8.5 & 7.3 & 8.9 & 21.2 \\
\hline Standard deviation & 1.7 & 1.9 & 0.9 & 1.1 & 0.9 & 1.8 & 3.2 \\
\hline HFHPC2-1 & 6.2 & 7.0 & 6.1 & 6.6 & 6.2 & 6.1 & 16.6 \\
\hline HFHPC2-2 & 12.3 & 13.8 & 7.3 & 14.8 & 7.9 & 11.6 & 29.1 \\
\hline HFHPC $2-3$ & 11.0 & 12.4 & 7.1 & 11.1 & 5.6 & 10.5 & 28.3 \\
\hline Mean value & 9.8 & 11.1 & 6.8 & 10.8 & 6.6 & 9.4 & 24.7 \\
\hline Standard deviation & 3.2 & 3.6 & 0.6 & 4.1 & 1.2 & 2.9 & 7.0 \\
\hline HFHPC3-1 & 8.5 & 9.6 & 8.4 & 8.8 & 8.9 & 8.1 & 22.1 \\
\hline HFHPC $3-2$ & 7.0 & 7.9 & 6.6 & 5.9 & 7.5 & 6.5 & 14.8 \\
\hline HFHPC $3-3$ & 6.8 & 7.7 & 6.5 & 5.8 & 6.2 & 4.2 & 14.3 \\
\hline Mean value & 7.4 & 8.4 & 7.2 & 6.8 & 7.5 & 6.3 & 17.1 \\
\hline Standard deviation & 0.9 & 1.0 & 1.1 & 1.7 & 1.3 & 2.0 & 4.4 \\
\hline PFHPC-1 & 5.1 & 5.7 & 2.6 & 1.8 & 2.4 & 1.0 & 4.5 \\
\hline PFHPC-2 & 5.0 & 5.6 & 2.5 & 1.7 & 2.3 & 0.9 & 4.0 \\
\hline PFHPC-3 & 5.4 & 6.1 & 2.8 & 2.4 & 2.8 & 1.3 & 6.2 \\
\hline Mean value & 5.2 & 5.8 & 2.6 & 2.0 & 2.5 & 1.1 & 4.9 \\
\hline Standard deviation & 0.2 & 0.3 & 0.1 & 0.4 & 0.3 & 0.2 & 1.1 \\
\hline
\end{tabular}
Tabela 9: Parametri natezne trdnosti in lomna energija pri preizkusih 

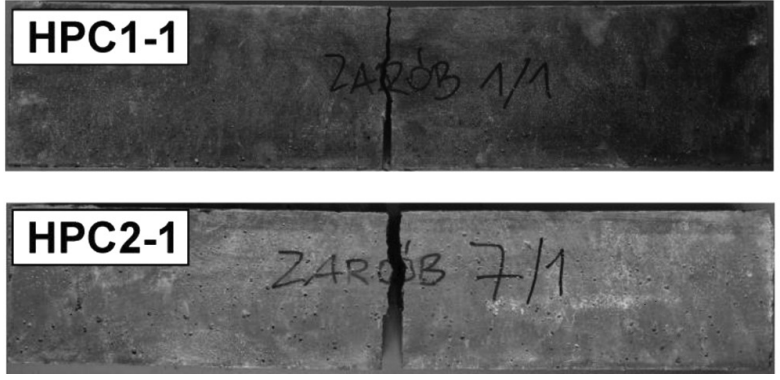

Figure 5: Notched HPC1 and HPC2 samples without fibers after the test Slika 5: Vzorci HPC1 in HPC2 z zarezo in brez vlaken po preizkusu
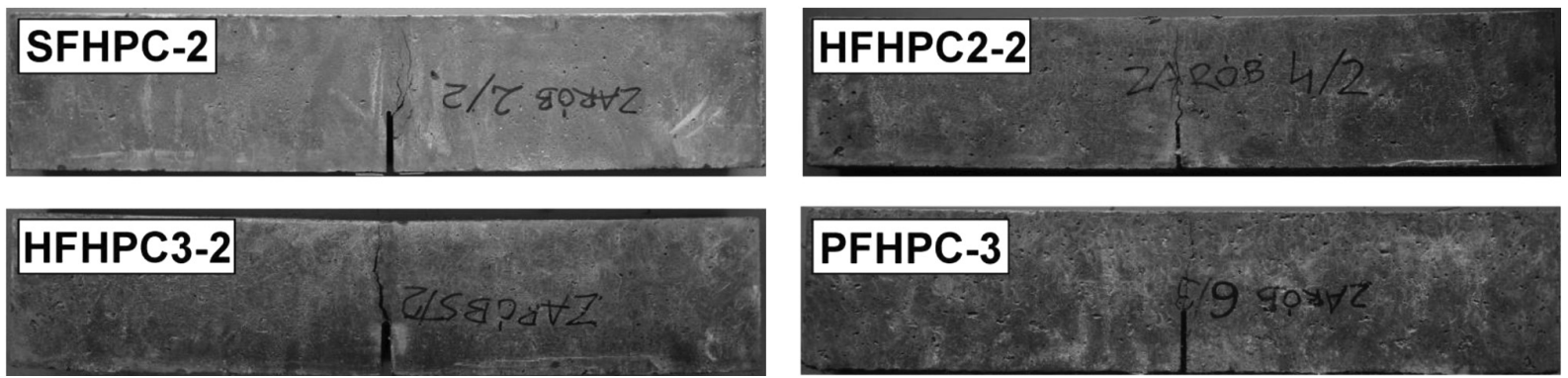

Figure 6: Notched FHPC samples after the test

Slika 6: Vzorci FHPC z zarezo po preizkusu

destruction of the samples caused by a separation into two parts occurred (Figure 6) as some bridges were formed by the fibers on the crack surface and limited the split.

The samples with the fibers exhibited a more ductile behavior and the main crack ran from the crack-opening tip to the upper edge of the beam (Figure 7).

\section{CONCLUSIONS}

The presence of steel fibers had an insignificant effect on the compressive strength of the high-performance concrete. Steel fibers increased the compressive strength by about $2.6 \%$ at a $1 \%$ fiber volume content. On the other hand, polypropylene fibers reduced the compression strength by about $37 \%$ at $1 \%$ fiber volumes. The addition of steel fibers in the amount of $0.5 \%$ and the polypropylene amounting to $0.5 \%$ caused an increase in the compressive strength by $3.4 \%$ as compared to the standard high-performance concrete HPC2.

The presence of the fibers had a significant impact on the splitting tensile strength of the high-performance concrete. However, the polypropylene fibers improved the splitting tensile strength by only $12 \%$ at a $1 \%$ fiber volume content, while the steel fibers at the same fiber volume content caused an increase in this parameter by $55 \%$. In the case of hybrid fibers the increase depended on the steel-fiber volume content and it was $(52,47$ and $37) \%$ for the $(0.75,0.5$ and 0.25$) \%$ steel fiber volumes, respectively.

The volume of the steel fibers was also a decisive factor regarding the modulus values for the high-perfor-
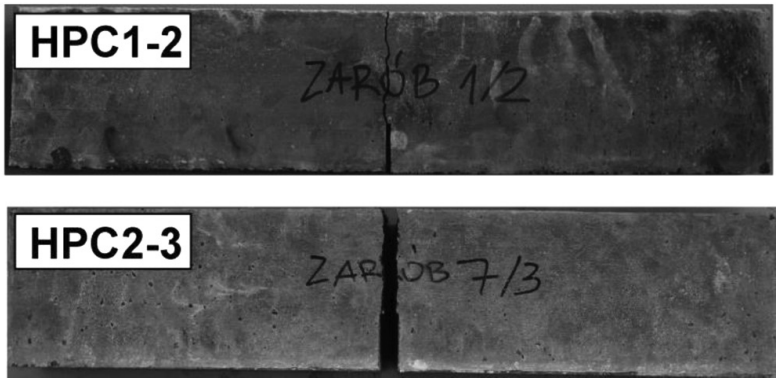




HPC2 peak load at the $1 \%$ fiber volume content. The highest increase in the peak flexural load of $92 \%$ was observed with the addition of the steel fibers in the amount of $0.5 \%$ and polypropylene fibers in the amount of $0.5 \%$. The SFHPC samples had the residual flexural strength at $17 \%$ of their peak-load values at a deflection of $3 \mathrm{~mm}$. The HFHPC and PFHPC samples which contained the fibers of a low elasticity modulus showed an abrupt decrease in the load capacity immediately after the peak load, while the load losses ranged from $10 \%$ for HFHPC 1 to $473 \%$ for PFHPC, depending on the volume fraction of the polypropylene fibers.

Increasing the content of the polypropylene fibers reduces the fracture energy. The $G_{\mathrm{F}}$ values for the high-modulus fibers should be numerically higher than the corresponding values for the low-modulus fibers. However, the fracture energy is not a measure of the efficiency and effectiveness of the fibers in inhibiting the cracks. In the load-deflection curves it can be seen that similar extensibilities are caused by the low-modulus fibers and the high-modulus ones.

Adding fibers to concrete has a significant effect on the splitting tensile strength, modulus of elasticity, flexural strength, fracture behavior, fracture energy and ductility. The factors that influence these properties of FHPC are the modulus of elasticity and geometry, the content and properties of the fibers.

A critical evaluation of the load-deflection curves of HPC and FHPC proves that the fibers help significantly to preserve the structural integrity and stability of the high-performance concrete. A combination of steel and polypropylene fibers should contribute to a long-term durable service life of a construction.

\section{REFERENCES}

${ }^{1}$ F. Bencardino, L. Rizzuti, G. Spadea, R. N. Swamy, Experimental evaluation of fiber reinforced concrete fracture properties, Composites Part B: Engineering, 41 (2010) 1, 17-24, doi:10.1016/ j.compositesb.2009.09.002

${ }^{2}$ RILEM PRO 31, Test and design method for steel fibre reinforced concrete -background and experience, Proceedings of RILEM TC 162-TDF workshop, 2003

${ }^{3}$ RILEM PRO 39, Fibre-reinforced concretes, Proceedings of sixth RILEM symposium on fibre-reinforced concretes BEFIB 2004, 2004

${ }^{4}$ M. di Prisco (Ed.), Fibre-reinforced concrete for strong, durable and cost-saving structures and infrastructures, Starrylink, Brescia 2007

${ }^{5}$ A. M. Brandt, Cement Based Composites: Materials, Mechanical Properties and Performance, Taylor and Francis, London, New York 2009, 526

${ }^{6}$ A. M. Brandt, Fibre reinforced cement-based (FRC) composites after over 40 years of development in building and civil engineering, Composite Structures, 86 (2008) 1-3, 3-9, doi:10.1016/j.compstruct. 2008.03.006

${ }^{7}$ J. C. Walraven, High performance fiber reinforced concrete: progress in knowledge and design codes, Materials and Structures, 42 (2009) 9, 1247-1260, doi:10.1617/s11527-009-9538-3

${ }^{8}$ M. di Prisco, G. Plizzari, L. Vandewalle, Fibre reinforced concrete: new design perspectives, Materials and Structures, 42 (2009) 9, 1261-1281, doi:10.1617/s11527-009-9529-4
${ }^{9}$ X. K. Li, L. Sun, Y. Y. Zhou, S. B. Zhao, A Review of Steel-polypropylene Hybrid Fiber Reinforced Concrete, Applied Mechanics and Materials, 238 (2012), 26-32, doi:10.4028/www.scientific.net/ AMM.238.26

${ }^{10}$ N. Banthia, R. Gupta, Hybrid fiber reinforced concrete (HyFRC): fiber synergy in high strength matrices, Materials and Structures, 37 (2004) 10, 707-716, doi:10.1007/BF02480516

${ }^{11}$ K. Komloš, B. Babal, T. Nürnbergerova, Hybrid fiber-reinforced concrete under repeated loading, Nuclear Engineering Design, 156 (1995) 1-2, 195-200, doi:10.1016/0029-5493(94)00945-U

${ }^{12}$ W. Sun, H. Qian, H. Chen, The effect of the combination of hybrid fibers and expansive agent on the physical properties of cementitious composites, Journal of the Chinese Ceramic Society, 2 (2000), 95-99

${ }^{13}$ Y. Liu, W. Qiu, D. Li, The shrinkage of steel-polypropylene hybrid fiber reinforced concrete, Materials Technology and Applications, 33 (2003), 27-30

${ }^{14}$ C. Yang, C. Huang, Y. Che, B. Wang, Mechanical properties and impermeability of hybrid fiber reinforced concrete, Journal of Building Materials, 1 (2008), 89-93

${ }^{15}$ S. P. Singh, A. P. Singh, V. Bajaj, Strength and flexural toughness of concrete reinforced with steel-polypropylene hybrid fibers, Asian Journal Of Civil Engineering (Building and Housing), 4 (2010), 495-507

${ }^{16}$ RILEM TC 50-FMC, Determination of the fracture energy of mortar and concrete by means of three-point bend tests on notched beams, Materials and Structures, 18 (1985) 4, 287-290, doi:10.1007/ BF02472918

${ }^{17}$ RILEM TC 89 -FMT, Fracture mechanics of concrete - test methods, Size-effect method for determining fracture energy and process zone size of concrete, Materials and Structures, 23 (1991), 461-465

${ }^{18}$ G. Golewski, T. S. Sadowski, Role of coarse aggregate in destruction of concrete composites subjected to summarily loads, IZT, 2008, 174 (in Polish)

${ }^{19}$ PN-EN 197-1:2002 Cement - Part 1: Composition, specifications and conformity criteria for common cements (in Polish)

${ }^{20}$ PN-B-19707:2013-10 Cement - Special cement - Composition, specifications and conformity criteria (in Polish)

${ }^{21}$ PN-EN 933-1:2000 Test for geometrical properties of aggregates Part 1: Determination of particle size distribution - Sieving method (in Polish)

${ }^{22}$ PN-EN 12390-3:2002 Testing hardened concrete - Part 3: Compressive strength of test specimens (in Polish)

${ }^{23}$ PN-EN 12390-6:2001 Testing hardened concrete - Part 6: Tensile splitting strength of test specimens (in Polish)

${ }^{24}$ ASTM C 469-02:2004 Standard Test Method for Static Modulus of Elasticity and Poisson's Ratio of Concrete in Compression

${ }^{25}$ RILEM TC 162-TDF, Test and design method for steel fibre reinforced concrete, Recommendations for bending test, Materials and Structures, 33 (2000) 225, 3-5

${ }^{26}$ RILEM TC 162-TDF, Test and design method for steel fibre reinforced concrete, Bending test, Final recommendation, Materials and Structures, 35 (2002) 253, 579-582

${ }^{27}$ RILEM TC 162-TDF, Test and design method for steel fibre reinforced concrete, $\sigma-\varepsilon$ design method, Final recommendation, Materials and Structures, 36 (2003) 262, 560-567

${ }^{28}$ F. Ozalp, Y. Akkaya, C. Sengul, B. Akcay, M. A. Tasdemir, A. N. Kocaturk, Curing effect on fracture of high-performance cement based composites with hybrid steel fibers, Proceedings of sixth international conference on fracture mechanics of concrete and concrete structures - FraMCoS-6, Catania, Italy, 3 (2007), 1377-85

${ }^{29}$ J. A. O. Barros, E. Pereira, A. Ribeiro, V. Cunha, Self-compacting steel fibre reinforced concrete for precasted sandwich panels experimental and numerical research, Proceedings of international workshop on advanced fiber reinforced concrete, Bergamo, Italy 2005, 169-80 